\title{
WUJUD KETIDAKADILAN GENDER DALAM NOVEL POPULER INDONESIA: PERSPEKTIF FEMINISME
}

\author{
Hanim Widayati \\ SMA Negeril Kembangbahu, Lamongan \\ HP085648007848; pos-el hanimwidayati@gmail.com
}

\begin{abstract}
Abstrak: Penelitian ini bertujuan untuk mengidentifikasi wujud ketidakadilan gender dalam novel populer Indonesia. Data penelitian ini bersumber dari novel yang berjudul Bibir Merah karya Achmad Munif yang diterbitkan oleh Navila pada Agustus 2004 dan Curahan Hati Sang SPG karya Wenda Koiman yang diterbitkan oleh Story House pada 2013. Data diperoleh dari teknik Baca, Simak dan Catat (BSC). Hasil penelitian menyatakan wujud ketidaadilan gender terhadap perempuan dalam novel populer Indonesia pertama, berupa stereotipe (pelabelan negatif): perempuan merupakan sosok yang matrealistis, perempuan mudah mengajak dan diajak tidur, serta perempuan merupakan objek permainan laki-laki. Kedua kekerasan, kekerasan seksual yang bertujuan demi kedudukan, sebagai korban perkosaan dan sebagai resiko pekerjaan. Kekerasan psikis yang berakibat ditanggapi biasa, tidak berdaya, kehilangan kemampuan untuk bertindak dan menimbulkan perang batin. Ketiga beban kerja.
\end{abstract}

Kata kunci: wujud ketidakadilan gender, feminisme

Abstract: The aim of this research was identify gender injustice in Indonesia's popular novel. The research data based on the novel had title Bibir Merah by Achmad Munif was published by Navila on August 2004 and Curahan Hati Sang SPG by Wenda Koiman was publised by Story house in 2013. Getting data by Read, View, and Record technique (BSC). Study result stated that (1) gender injustice based on indonesia's populer novel such as first negative labeling/ stereotypes: woman as a materialistic, whore easily and a playful object for man. Second, abuse: sexual abuse purpose for position as sexual abuse victim and working risk. Psychological abuse respond was common condition, weak, incapable for doing and internal conflict happen. Third, double burden.

Keywords: gender injustice, feminism

\section{PENDAHULUAN}

Sastra populer karya pengarang laki-laki yang berjudul Bibir Merah dan Curahan Hati Seorang SPG adalah novel populer yang berkisah tentang kehidupan perempuan yang bernama Rere dan Rumanti. Dalam kedua novel populer tersebut yang menjadi sentral cerita adalah tokoh perempuan yang mengalami ketidakadilan gender akibat budaya patriarki yang membelenggu mereka.

Tokoh-tokoh perempuan tersebut yang diceritakan oleh pengaraang lakilaki yang akan menjadi bahan analisis dengan menelusuri ketidakadilan gender yang mereka alami melalui pengaruh budaya patriarki. Pengaruh budaya patriarki inilah yang membuat penulis tertarik untuk meneliti lebih jauh 
permasalahan tentang gender yang ada dalam kedua novel tersebut.

Secara umum, keadaan di lingkungan sekitar kita saat ini masih memperlihatkan dan menempatkan perempuan menjadi kaum yang termarjinalkan, bahkan menjadi korban dan pelampiasan. Selain itu, masih banyak pula perlakuan masyarakat yang mempekerjakan kaum perempuan dikantor, pabrik, ladang, dan sawah dengan dinilai dan dihargai lebih rendah dari yang diperoleh kaum laki-laki. Bahkan Fakih (2007:13)menyatakan bahwa pekerjaan-pekerjaan yang diberikan kepada kaum perempuan justru pada sektor-sektor yang tidak membutuhkan kecerdasan dan keterampilan tinggi.

Berdasarkan realita yang terjadi di masyarakat lahirlah karya sastra, satu diantaranya adalah novel populer. Menurut Umar Kayam (1981:82) sebutan novel populer atau novel pop. Mulai merebak sesudah suksesnya novel Karmila dan Cintaku di Kampus Biru pada tahun 70-an. Hal ini ditandai dengan semakin besarnya jumlah pembaca sastra dengan latar belakang sekolah menengah dan perguruan tinggi. Pembaca sastra populer ini kebanyakan adalah perempuan remaja dan ibu rumah tangga. Namun, kesusasteraan populer tidak lahir begitu saja di tahun itu. Menurut Jakob Sumardjo, kesusasteraan populer yang berkonotasi hiburan dan barang dagangan sudah sudah muncul sejak tahun 30-an, ketika Balai Pustaka sedang merajalela (Sumardjo, 1982: 37-39). Sesudah itu novel hiburan tidak peduli mutunya, disebut juga novel populer. Kata populer erat diasosiasikan dengan kata populer, mungkin karena novel-novel itu sengaja ditulis untuk "selera populer" yang kemudian dikenal sebagai bacaan populer. Dan jadilah istilah "pop" itu sebagai istilah baru dalam dunia sastra. Sebagai kebalikan sastra populer itu adalah sastra yang "sastra". "Sastra serius", literature. Sastra serius, walau dapat juga berupa inovatif dan eksperimental, tak akan dapat menjelajah sesuatu yang mirip dengan "main-main" (Kayam. 1981: 85-87).

Sastra populer merupakan cermin yang merefleksikan kondisi masyarakat serta tempat karya sastra itu tercipta. Selain itu, bisa juga merupakan refleksi ungkapan hati seseorang akan kenyataan hidup yang dilihat, didengar, dialami atau dirasakan. Hal ini disebabkan oleh adanya permasalahan yang timbul yang menginginkan adanya perlakuan yang adil antara kaum laki-laki dan kaum perempuan. Oleh karena itu, studi karya sastra dari segi feminisme, bagian terpenting dalam pembicaraan tentang perempuan adalah mengetahui wujud ketidakadilan genderdidalam sebuah karya sastra. wujud tersebut sangat dipengaruhi oleh kepekaan pengarang dalam menangkap fenomena yang ada dalam masyarakat dan bagaimana pengarang mengekspresikan apa yang dilihat, didengar, dirasakan, dipikirkan, dan diharapkannya terkait dengan situasi dan kondisi yang ada dalam suatu masyarakat. Feminisme berkaitan erat dengan kritik sastra feminis yakni kajian karya sastra yang mendasarkan pada pandangan feminisme yang menginginkan adanya keadilan dalam memandang eksistensi perempuan.

Pembicaraan tentang perempuan secara serius menurut Djajanegara (2000:1) dilakukan pada pertengahan abad ke-19 diAmerika Serikat yaitu dengan diadakannya konvensi di Seneca Falls pada tahun 1848, yang dianggap sebagai awal timbulnya gerakan perempuan secara terorganisasi dan yang dianggap pula sebagai Women's Great Rebellion (Pemberontakan Besar Kaum Perempuan). Mereka memproklamasikan versi lain dari deklarasi Kemerdekaan Amerika yang berbunyi: "All man and 
women are created equal" ("Semua lakilaki dan perempuan diciptakan sama"). Gerakan inilah yang dinamakan feminisme.

Pada 1960-an tujuan-tujuan politik feminis berfokus pada penentuan wanita agar sederajat dengan laki-laki (gross dalam Ollenburger dan Moore, 1996: 20). Sejak saat itulah timbul perhatian besar terhadap wanita baik di dalam maupun di luar negeri.

Dalam penelitian ini karya sastra yang akan diteliti berbentuk novel populer. Ada dua judul novel yang akan diteliti, kedua novel tersebut karya lakilaki. Penulis merasa tertarik untuk memilih kedua novel tersebut untuk diteliti. Pemilihan itu, didasarkan pada alasan (1) Di dalam kedua novel tersebut terdapat berbagai gambaran ketidakadilan gender; ketidakadilan gender akibat kepala desa yang merasa menjadi "raja kecil" dan bertindak semena-mena dan ketidakadilan gender akibat patriarki, (2) Biasanya counter hegemony hanya dilakukan oleh penulis perempuan melawan dominasi ideologi patriarkis melalui karya-karyanya tetapi, dalam novel ini dilakukan oleh penulis laki-laki. (3) sampai sekarang, sastra populer Indonesia jarang dipilih sebagai bahan penelitian, sebagian besar karya sastra yang sering dipilih sebagai bahan penelitian berupa novel sastra, cerpen dan puisi.

Ketidakadilan gender merupakan sistem dan struktur yang memungkinkan kaum laki-laki maupunperempuan menjadi korban dari sistem tersebut. Ketidakadilan gender termanifestasikan dalam berbagai bentukketidakadilan, yaknimarginalisasi atau proses pemiskinan ekonomi, subordinasi atau anggapan tidak penting dalam keputusan politik, pembentukan stereotipe atau melalui pelabelan negatif, kekerasan (violence), beban kerja lebih panjang dan lebih banyak (brden), serta sosialisasi ideologi nilai peran gender (Fakih, 2008: 12-13).

Marginalisasi merupakansuatu tindakan yang menempatkan perempuan ke pinggiran dan kemudian membatasi segala bentuk aktivitas dan kreativitas seorang perempuan. Perempuan diciptakan sebagai individu yang lemah, kurang dan tidak rasional, kurang dan tidak berani, sehingga tidak pantas untuk memimpin (Murniati, 2004). Marginalisasi terhadap perempuan sudah terjadi sejak di rumah tangga dalam bentuk diskriminasi atas anggota keluarga yang laki-laki dan perempuan. Marginalisasi juga diperkuat oleh adat istiadat maupun tafsir keagamaan (Fakih, 2008: 15).

Pandangan gender ternyata bisa menimbulkan subordinasi terhadap perempuan. Anggapan bahwa perempuan itu irrasional atau emosional sehinga perempuan tidak bisa tampil memimpin, berakibat munculnya sikap yang menempatkan perempuan pada posisi tidak penting (Fakih, 2008: 15).

Secara umum stereotipe adalah pelabelan atau penandaan terhadap suatu kelompok tertentu. Celakanya, stereotipe selalu merugikan dan menimbulkan ketidakadlian (Fakih, 2008: 16). Banyak sekali ketidakadilan terhadap jenis kelamin tertentu,umumnya perempuan, yang bersumber dari penandaan (stereotipe) yang dilekatkan kepada mereka. Misalnya, penandaan yang berawal dari asumsibahwa perempuan bersolek adalah dalam rangka memancing perhatian lawan jenisnya, maka setiap kasus kekerasan atau pelecehan seksual selalu dikaitkan dengan stereotipe ini (Fakih, 2008: 1617).

Kekerasan (violence) adalah serangan atau invasi (assault) terhadap fisik maupun integritas mental psikologis seseorang. Kekerasan terhadap sesama manusia pada dasarnya berasal dari 
berbagai sumber, namun salah satu kekerasan terhadap satu jenis kelamin tertentu yang disebabkan oleh anggapan gender (Fakih, 2008: 17).Adanya anggapan bahwa kaum perempuan memiliki sifat memelihara dan rajin, serta tidak cocok untuk menjadi kepala rumah tangga, berakibat bahwa semua pekerjaan domestik rumah tangga menjadi tanggung jawab kaum perempuan. Di kalangan keluarga miskin beban yang sangat berat ini harus ditanggung oleh perempuan sendiri. Terlebih-lebih jika si perempuan tersebut harus bekerja, maka ia memikul beban ganda (Fakih, 2008: 21).

Perempuan menanggung beban kerja domestik lebih banyak dan lebih lama (burden). Adanya anggapan bahwa kaum perempuan memiliki sifat memelihara dan rajin, serta tidak cocok untuk menjadi kepala rumah tangga, berakibat bahwa semua pekerjaan domestik rumah tangga menjadi tanggung jawab kaum perempuan. Di kalangan keluarga miskin beban yang sangat berat ini harus ditanggung oleh perempuan sendiri. Terlebih-lebih jika si perempuan tersebut harus bekerja, maka ia memikul beban ganda (Fakih, 2008: 21).

Berdasarkan paparan di atas, masalah yang perlu dikaji dalam penelitian ini adalah wujud ketidakadilan gender yang dialami para tokoh perempuan dalam novel populer Indonesia.

\section{METODE PENELITIAN}

Pendekatan yang digunakan dalam penelitian ini adalah pendekatan kualitatif yang bersifat deskriptif.Dalam penelitian ini data yang diambil berupa kata, frasa, kalimat dan paragraf yang diambil dari sumber data. Data yang akan dianalisis dalam penelitian ini terutama yang berbicara tentang wujud ketidakadilan gender berdasarkan perspektif feminisme.
Pada penelitian ini yang dijadikan sumber data adalah novel yang berjudul Bibir Merah karya Achmad Munif yang diterbitkan oleh Navila pada Agustus 2004 dan Curahan Hati Sang SPG karya Wenda Koiman yang diterbitkan oleh Story House pada 2013.

Teknik yang digunakan dalam pengumpulan data adalah teknik baca, simak dan catat. Teknik ini dikemukakan oleh Ratna (2010: 245-246). Membaca dalam pengumpulan data teks novel dilakukan dengan cara memberikan perhatian yang benar-benar terfokus pada obyek. Proses membaca dengan memberikan perhatian penuh terhadap obyek disebut sebagai proses menyimak kemudian diikuti dengan kegiatan mencatat data.

Teknik analisis data yang digunakan oleh peneliti ini adalah teknik kualitatif yang dikembangkan oleh Milles dalam Huberman dalam Ratna (2010: 309-311) yaitu dimulai dengan mengumpulkan data, reduksi data, penyajian data, dan penarikan simpulan.Langkah-langkah konkret analisis data dalam peneliti ini disajikan sebagai berikut: (1) mengklasifikasikan data dari proses pembacaan novel populer karya Ahmad Munif dan Wenda Koiman untuk menggambarkan wujud ketidakadilan gender.Penyajian data dilakukan dengan (2) mencatat secara seksama dan mengelompokkan frasa, kata, kalimat,ungkapan yang sesuai dengan wujud ketidakadilan gender ke dalam tabel,(3) merumuskan simpulan hasil penelitian.

\section{HASIL PENELITIAN DAN PEMBAHASAN \\ Wujud Ketidakadilan Gender yang Dialami Para Tokoh Perempuan}

Dari hasil penelitian, ditemukan beberapa wujud ketidakadilan gender dalam novel populer BMkarya Ahmad Munif dan CHSSPG karya Wenda 
Koiman. Wujud-wujud ketidakadilan gender tersebut berupa sterotipe/ pelabelan negatif, kekerasan yang berupa kekerasan seksual dan kekerasan psikis serta beban kerja.

\section{Stereotipe}

Stereotipe perempuan dalam karya sastra dapat dilihat pada lakuan dan pikiran tokoh-tokoh cerita (Sugihastuti, 2015: 289). Stereotipe atau pelabelan negatif yang dialami oleh tokoh-tokoh dalam novel populer diantaranya sebagai berikut:

\section{Perempuan merupakan Sosok yang Matrealistis}

Menurut pandangan gender perempuan adalah makhluk yang matrealistis, yang mengukur laki-laki dari segi materi. Bayan Sardi tahu betul siapaan ledek Murtini yang mata duwitan itu. Perempuan itu selalu mengukur lakilaki dengan isi kantongnya. Tebal atau tipis (Munif, 2004: 83).

Dalam novel CHSSPG lelaki juga memberi pelabelan negatif kepada Rere seorang SPG bahwa hati perempuan dapat diluluhkan dengan materi.

"Udah mau belum jalan sama aku? Kan sekarang aku udah punya mobil"(Koiman, 2013: 94). Hal ini menunjukkan prasangka gender membenarkan adanya pepatah yang mengatakan bahwa ada uang abang sayang, tak ada uang abang malang. Padahal tidak semua hati wanita dapat dibeli dengan materi. "Maaf... saya gak pake BB", niatnya jelas udah lain nih orang. "Gak punya $B B$ ? Mau gue beliin?" Salah target (Koiman, 2013: 31).

\section{Perempuan Mudah Mengajak dan Diajak Tidur}

Stereotipe yang berprasangka gender pun dianut oleh masyarakat setempat, Menurut Kartono (1992:31) dengan segala upaya ibu itu akan berusaha untuk melindungi anaknya dari segala macam mara bahaya yang bersifat lahiriyah maupun batiniah. Ibu Mustain tidak rela jika anaknya dekat dengan perempuan yang memiliki karakter jelek.

"Ibu ini kan takut kamu kecantol Murtini. Bukan karena martini itu ledek. Ledek itukan juga seniwati. Tapi seharusnya kamu tahu siapa Murtini. Murtini itu kan Ledek yang lenjeh,geleman, gampang mengajak dan diajak tidur. Tidak semua ledek begitu, tapi Si Mur begitu" (Munif, 2004: 125).

Dalam pandangan masyarakat ledek identik dengan sifat murahan. Mudah mengajak dan diajak tidur oleh laki-laki.

\section{Perempuan Merupakan Objek Permainan Laki-Laki}

Stereotipe atau pelabelan yang dialami oleh Rusmini dan Rusminah (Rumanti) adalah pelabelan yang diberikan oleh masyarakat. Masyarakat beranggapan bahwa seorang perempuan yang memiliki wajah cantik rawan dengan godaan."Percaya saya nduk, anjuran saya ini baik. Kalian pandai memetik siter. Suara kalian bagus. Di Yogya kamu pasti laris. Tapi ingat nduk, wajah kalian cantik-cantik. Orang cantik selalu menemui banyak godaan. Tergantung kalian apakah kalian bisa menahan godaan itu. (Munif, 2004: 177).

Berdasarkan kutipan-kutipan mengenai stereotipe atau pelabelan dalam novel ini menunjukkan bahwa perempuan sering mendapatkan pelabelan negatif dari dominasi patriarki dan dari orangorang sekitar. Perempuan harus menerima ketidakadilan yang menimpah, Perempuan menjadi pihak yang terpinggirkan karena dominasi patriarkat yang menimbulkan ketidakadilan.

\section{Kekerasan ( Violence)}

Kekerasan terhadap sesama manusia pada dasarnya berasal dari berbagai sumber, namun salah satu kekerasan terhadap satu jenis kelamin tertentu yang disebabkan oleh anggapan gender (Fakih, 2008: 17).Kekerasan yang dialami oleh tokoh-tokoh perempuan 
dalam BMkarya Ahmad Munif dan CHSSPG karya Wenda Koimanadalah dalam bentuk kekerasan seksual dan kekerasan psikis.

\section{Kekerasan Seksual}

Undang-Undang PDKRT (via Wiyatmi, 2012: 210) menyebutkan bahwa kekerasan seksual adalah setiap perbuatan yang berupa pemaksaan hubungan seksual, pemaksaan hubungan seksual dengan cara tidak wajar dan/atau tidak disukai, pemaksaan hubungan seksual dengan orang lain untuk tujuan komersial dan/atau tujuan tertentu.

Kekerasan seksual dialami oleh istri bento yang dijadikan korban oleh suaminya sendiri untuk melayani lakilaki lain demi mendapatkan kedudukan sebagai Bayan. Bento sebagai suami tidak merasa bersalah dengan apa yang dilakukannya dan Bento hanya diam. Perempuan itu memukuli dada suaminya. Tangisnya makin keras. Bento membiarkan saja istrinya memukuli dadanya. Lelaki itu diam terpaku. Nista, nista, memang nista. Iblis mana yang telah membujuknya untuk menjual istrinya demi kedudukan? Bayan Bento mengelus rambut istrinya (Munif, 2004: 166).

Berbeda dengan kekerasan seksual yang dialami Rusmini dan Rusminah, mereka menjadi korban perkosaan yang dilakukan laki-laki untuk memenuhi nafsu bejatnya.

Keadaan menjadi sepi kembali. Rusminah dan adiknya menangis terus. Tiba-tiba muncul seorang lelaki memakai topeng. Rusminah dan Rusmini ketakutan. Lelaki itu mendekat langsung menyeretnya ke tempat tidur, sementara Rusmini mencoba menghalangi perbuatan lelaki itu. Tapi lelaki itu menendangnya dan adiknya terkapar di lantai. Lelaki itu dengan leluasa menjamah seluruh tubuhnya. Dengan sekuat tenaga Rusminah melawan. Namun lelaki itu terlalu kuat (Munif, 2004: 173).

Upaya yang dilakukan Rusmini dan Rusmina untuk melawan kekerasan seksual yang dialaminya sia-sia karena lelaki itu terlalu kuat. Rusmini dan Rusminah tidak berdaya melawannya.

Hasrat seksual merupakan sebuah ungkapan dan pemenuhan cinta. Adapun realisasi seksual seseorang dipengaruhi oleh latar belakang kehidupan pribadi. Ini sesuai dengan pendapat Fromm (2002:199) yang mengatakan bahwa karakteristik kehidupan seksual dari seorang manusia dianggap representasi yang sempurna dari kepribadian secara keseluruhan.

Lelaki yang mengalami sadomasohis merasakan kepuasan seksual jika menyiksa terlebih dahulu lawan mainnya. Demi mendapatkan pemenuhan materi Nadia harus rela menjadi korban kekerasan seksual yang dianggapnya sebagai resiko pekerjaan.

Matanya tetep ke arah TV, Cuma tangannya yang diulurkan ke gue. Pergelangan tangannya merah kaya lecet.

"Kena apaan? Sampe kaya gini?"

"Biasa.. resiko pekerjaan. Untung aja Anjing satu itu ngasih tip gede, kalo gak rasanya pengen gue kepruk pake botol kepalanya”

"Emangnya diapain?"

"Diiket pake borgol"

"Hah? Serem banget?"

"Buat kita serem, buat dia itu fun.Sadomasohis.

“Ooh..” gue mulai nangkep. (Koiman, 2013: 47)

Berdasarkan kutipan dialog tersebut, tokoh Nadia merupakan objek kekerasan seorang laki-laki. Dalam melakukan hubungan seksual, laki-laki memiliki karakter otoriter,yang mengutamakan kepuasan seksual meskipun pasangan seksnya menderita kesakitan fisik dan emosional (Fromm, 2002: 201).

\section{Kekerasan Psikis}

Kekerasan psikis adalah perbuatan yang mengakibatkan ketakutan, hilangnya rasa percaya diri, hilangnya kemampuan untuk bertindak, rasa tidak berdaya, dan/atau penderitaan psikis berat pada seseorang (Wiyatmi, 2012: 210). Kekerasan psikis dialami istri Bayan 
Sardi yang menjadi korban kemarahan suami yang tidak beralasan. Bayan Sardi memperlakukan istrinya dengan kasar, mencelah istrinya. Namun, istri Bayan Sardi tidak menderita akibat perlakuan suaminya, ia menanggapi sebagai hal yang biasa.

Sampai di rumah Bayan Sardi marah-marah kepada istrinya tanpa alasan. Tapi istrinya diam saja. Ia sudah hapal betul kalau hujan, tanpa angin suaminya marah-marah begitu pasti ada persoalan gawat di kelurahan.setelah marahmarah Bayan Sardi menghempaskan tubuhnya di tempat tidur. Persetan teriaknya dalam hati. Yang penting nanti malam mengetuk rumah Munah. Hari itu dadanya terasa sesak dan ia perlu kegembiraan. Salah satu caranya mendatangi Munah. Bayan Sardi memang tidak ubahnya seperti Lurah Koco (Koiman, 2013: 70).

Perlakuan Bayan Sardi terhadap istrinya menunjukkan sikap egois seorang laki-laki, yang hanya ingin menang sendiri. Istri sebagai pasangan hidup harus menerima akibat kegalauan hati suami tetapi, suami malah menghendaki untuk bersenang-senang, selingkuh dengan perempuan lain.

Pada umunya, kekerasan dalam rumah tangga dilakukan oleh suami dengan korban istri. Kekerasan seperti ini dikenal dengan istilah kekerasan berbasis gender (gender based violence) karena prosesnya sebagian disebabkan oleh status gender perempuan yang tersubordinasi dalam masyarakat (Wiyatmi, 2012: 210).

Kekerasan psikis yang dialami Rere berbeda dengan kekerasan psikis yang dialami istri bayan Sardi. Selain itu, kekerasan psikis yang dialami Rere juga mengakibatkan terjadinya perang batin dalam diri Rere. Kutipan berikut menunjukkan penderitaan yang dialami Rere:

Gue menerima kain itu dengan perasaan campur aduk. Gue bakalan pake ini? Ini bahkan gak bisa disebut mini dress. Tanpa lengan, bahkan terkesan memberikan banyak celah untuk melihat bagian samping payudara, tipis. Dan warna goldnya yang mencolok ni pastinya bakal ngejrenng banget menyambut sorotan lampu. Sama aja gak pake baju (Koiman, 2013:5-6).

Secara psikis Rere keberatan untuk memakai mini dress yang memperlihatkan bagian tubuhnya. Bagi Rere hal itu sama dengan ia telanjang di hadapan umum. Kekerasan yang dialami Rere ini juga merupakan akibat ketidakadilan gender.

Bentuk-bentuk kekerasan yang dilakukan oleh tokoh laki-lakidalam novel BM dan CHSSPG mulai dari kekerasan psikishinggakekerasan seksualmenunjukkan adanya ketidakadilan yang menimpa tokoh-tokoh perempuan. Kekerasan dilakukan karena kaum laki-laki merasadirinyalebih kuat dan menganggap perempuan sebagai kaum yang lebih lemah.

Wujud ketidakadilan gender berupa kekerasan yang menimpa perempuan dalam kedua novel tersebut menunjukkan bahwa laki-laki menempati posisi yang dominan. Dominasi patriarkat ditunjukkan melalui perempuan dijadikan sebagaiobjek kekerasan yang dilakukan oleh laki-laki. Kekerasan psikis dan kekerasan seksual yang dilakukan oleh tokoh laki-laki menjadikan tokoh perempuan sebagai pihak yang tertindas.

\section{Beban Kerja}

Budiman (1981:38) mengatakan faktor-faktor yang mempertahankan pembagian kerja secara seksual dapat dibagi menjadi dua kelompok. Pertama, faktor-faktor yang didasarkan pada kebutuhan sosial ekonomi masyarakat. Kedua faktor-faktor yang didasarkan pada sistem psikokultural dengan lembaga-lembaga kemasyarakatan yang menyebarkannya dan mengembangbiakkan sistem pembagian kerja.

Berdasarkan uraian di atas penyebab perempuan bekerja karena dua alasan. Alasan pertama, karena tuntutan ekonomi dan alasan kedua karena 
eksistensi diri. Dalam novel CHSSPG melalui tokoh Rere digambarkan sosok perempuan pekerja keras karena tuntutan ekonomi. Sebagai seorang SPG ia rela setiap hari berpindah dari stand satu ke stand lain. Hal tersebut dia lakukan untuk mewujudkan cita-citanya agar bisa kuliah.

Setiap hari pontang-panting pindah dari satu stand ke stand lain. dari event A ke event B. Cuma itu yang bikin gue lakuin kalo gak mau cita-cita gue untuk bisa kuliah seperti yang lain bisa terwujud. (Koiman, 2013: 19).

Udah empat tahun, hampir gak ada perubahan berarti. Emang sih, ada kok beberapa hasil yang dapet. Kebanggaan karena bisa move on dengan keringat sendiri. Segala benda di kamar ini meskipun gak ada yang istimewa tapi setidaknya bisa gue dapat dengan jerih payah yang sah. Yang gue sebut perubahan berarti adalah bahwa: di empat tahun terakhir ini, gue tetep harus jadi Sales Promotion Girls. Just SPG, tanpa embelembel lain (Koiman, 2013: 19)

Secara seksual Rere mampu menjalankan beban ganda yaitu sebagai pekerja dan sebagai mahasiswa. Sebagai pekerja ia sering menerima perlakuan yang tidak baik dari laki-laki. Beban kerja yang dialami oleh tokohperempuantersebutmenunjukkan bahwa perempuan tidak sepenuhnya dihargai oleh laki-laki. Perempuan harus menanggung beban kerja ganda yaitu dalam sektor pendidikan dan dalam sektor publik.

\section{SIMPULAN DAN SARAN}

Berdasarkan hasil penelitian dan pembahasan mengenai Ketidakadilan Gender dalam Novel Populer Indonesia: Perspektif feminisme dapat disimpulkan bahwa wujud ketidaadilan gender terhadap perempuan dalam novel populer Indonesia pertama, berupa stereotipe (pelabelan negatif): perempuan merupakan sosok yang matrealistis, perempuan mudah mengajak dan diajak tidur, serta perempuan merupakan objek permainan laki-laki. kedua kekerasan, kekerasan seksual yang bertujuan demi kedudukan, sebagai korban perkosaan dan sebagai resiko pekerjaan. kekerasan psikis yang berakibat ditanggapi biasa, tidak berdaya, kehilangan kemampuan untuk bertindak dan menimbulkan perang batin. Ketiga beban kerja.

Hasil penelitian mengenai novel populer Indonesia yang menggunakan pendekatan kritik sastra feminis dapat dijadikan alternatif untuk menambah apresiasi sastra dan dapat dijadikan sebagai wawasan terhadap masalahmasalah yang dialami perempuan di dalam masyarakat.Penelitian ini juga diharapkan dapat menjadi salah satu rujukan dalammengkaji ketidakadilan gender terhadap perempuan yang terdapat dalam novel populer Indonesia. Penelitian ini hanya terbatas pada seputar ketidakadilan gender yang dialami oleh perempuan dengan pendekatan kritik sastra feminis. Oleh karena itu, penelitian ini diharapkan dapat dikembangkan dengan menggunakan perspektif telaah sastra lain. Disarankan bagi peneliti lain untuk mengembangkan penelitian ini dengan menggunakan perspektif sosiologi sastra atau perspektif psikologi sastra.

\section{DAFTAR PUSTAKA}

Munif, Ahmad. 2004. Bibir Merah. Yogyakarta: Navila.

Budiman, Arief. 1981. Pengembangan Kerja Seksual: sebuah Pembahasan Sosiologi tentang Peran Wanitadi dalam Masyarakat. Jakarta: Gramedia.

Djajanegara, Soenarjati. 2000. Kritik Sastra Feminis: Sebuah Pengantar. Jakarta: Gramedia.

Fakih, Mansour. 2007. Analisis Gender dan Transformasi sosial.Yogjakarta: Pustaka Pelajar. 
Fakih, Mansour. 2008.Analisis Gender dan Transformasi Sosial. Yogyakarta: Pustaka Pelajar.

Fromm, Erich. 2001. Cinta, Seksualitas Matriarki dan Gender. Di Indonesiakan Oleh Pipit Maizier. Yogyakarta: Jalasutra.

Kartini, Kartono. 1992. Psikologi Wanita (Jilid 2): Mengenal Wanita sebagai Ibu dan Nenek. Bandung: Mandar Maju.

Kayam, Umar. 1981. Seni Tradisi Masyarakat. Jakarta: Grafiti.

Koiman, Wenda. 2013. Curahan Hati Sang SPG. Jakarta: Story Hause.

Murniati, Nunuk A. 2004. Getar Gender. Magelang: Indonesia Tera.
Ollenburger, Jane C. dan Moore, Helen A. 1996. Sosiologi Wanita. Di Indonesiakan oleh Budi Cahyono dan Yan Sumaryana. Jakarta: Rhineke Cipta.

Ratna, nyoman Kutha. 2010. Metodologi Penelitian: Kajian Budaya dan Humaniora pada Umumnya. Yogyakarta: Pustaka Pelajar.

Sugihastuti. 2015. Kritik sastra Feminis teori dan Aplikasinya. Yogyakarta: pustaka Pelajar Ofset.

Sumardjo, Jakob. 1981. Segi Sosiologis Novel Indonesia. Bandung: Pustaka Prima.

Wiyatmi. 2012. Kritik Sastra Feminis: Teori dan Aplikasinya dalam Sastra Indonesia.Yogyakarta: Penerbit Ombak. 


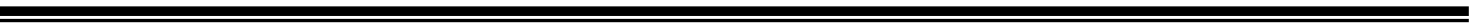

